\title{
Jean Claude Hauc, Ange Goudar, un aventurier des Lumières
}

Jean-Paul De Nola

\section{(2) OpenEdition}

10 Journals

\section{Édition électronique}

URL : http://journals.openedition.org/studifrancesi/30346

DOI : 10.4000/studifrancesi.30346

ISSN : 2421-5856

Éditeur

Rosenberg \& Sellier

\section{Édition imprimée}

Date de publication : 1 avril 2006

Pagination : 161-162

ISSN : 0039-2944

\section{Référence électronique}

Jean-Paul De Nola, "Jean Claude Hauc, Ange Goudar, un aventurier des Lumières », Studi Francesi [En ligne], 148 (XLX | I) | 2006, mis en ligne le 30 novembre 2015, consulté le 22 avril 2021. URL : http:// journals.openedition.org/studifrancesi/30346 ; DOI : https://doi.org/10.4000/studifrancesi.30346

Ce document a été généré automatiquement le 22 avril 2021.

\section{(c) (i) (9)}

Studi Francesi è distribuita con Licenza Creative Commons Attribuzione - Non commerciale - Non opere derivate 4.0 Internazionale. 


\section{Jean Claude Hauc, Ange Goudar, un aventurier des Lumières}

Jean-Paul De Nola 


\section{RÉFÉRENCE}

JEAN ClaUde HaUc, Ange Goudar, un aventurier des Lumières. Paris, Champion, 2004, pp. 208.

1 Voici la biographie d'un chevalier d'industrie, qui était aussi débauché, proxénète, grec (= tricheur au jeu de cartes), espion de police, filou, fripon... et graphomane. Ce mauvais sujet, complice et rival de Casanova, a laissé des traités de politique et d'économie non dépourvus d'intérêt: son Testament politique de Louis Mandrin, Généralissime des troupes de contrebandiers (1755) est une critique violente de la Ferme (= perception des impôts par des exacteurs privés), ses Intérêts de la France mal entendus (1756) épousent les thèses des physiocrates, agrariens et «populationnistes». L'Espion chinois (1764) est un roman épistolaire dans le sillage des Lettres persanes. Dans Naples, ce qu'il faut faire pour rendre ce royaume florissant (1769) Goudar propose un programme de développement de l'agriculture, des «arts» et du commerce aux pieds du Vésuve.

2 La vie peu recommandable de ce polygraphe est attentivement suivie par M. Hauc, sur la base des travaux bibliographiques du regretté Francis L. Mars et de documents d'archives inédits, depuis l'enfance et l'adolescence à Montpellier (où il naquit en 1708), à travers le voyage à Constantinople, les périodes répétées de résidence à Paris, entrecoupées de longs séjours au Portugal, en Avignon et surtout en Italie et en Angleterre, jusqu'à sa vieillesse aigrie (qui le voit tenancier d'un tripot-lupanar au Palais-Royal) et sa disparition en pleine tourmente révolutionnaire (probablement en 1791).

Quant à l'œuvre de cet «aventurier des Lumières», on partage l'avis de J.C. Hauc, qui la juge «inégale, brouillonne, parmi laquelle les pépites se mêlent au gravier le plus vil» (p. 189). La présence de ces "pépites» justifie l'attribution, par les contemporains, du Testament politique de Louis Mandrin à Voltaire: le compliment n'était pas mince! 